\title{
Intellectual Activity Index of the National Innovation System: Assessment and Analysis
}

\author{
Elena E. Golovchanskaya ${ }^{1 *[O R C I D}$ 0000-0001-8824-9326], \\ Irina A. Karachun 2[ORCID 0000-0002-0132-5064], \\ Yury V. Daneykin 3[ORCID 0000-0001-7181-2557]
}

\author{
${ }^{1}$ LEONOV Moscow Region University of Technology, Korolev, Russia \\ ${ }^{2}$ Belarusian State University, Minsk, Republic of Belarus \\ ${ }^{3}$ Yaroslav-the-Wise Novgorod State University, Veliky Novgorod, Russia \\ golovchanskaja2011@yandex.by
}

\begin{abstract}
The article analyzes the dynamics of intellectual activity index (hereinafter - IAI) of the national innovation system (hereinafter - NIS) as an object of socio-economic development of the Republic of Belarus. Improving the methodology for strategizing the NIS development by introducing the methodology for IAI determining into the statistical database will help define the additional guidelines for its development. A comprehensive assessment of the NIS is performed by determining the IAI of its effectiveness. The developed structure of the IAI includes subindices: 1) "Management" to evaluate the institutional environment; 2) "Science" as a result of research and development; 3) "Intellectual resources" to determine the quality and number of researchers in the innovative production system; 4) "Innovations" to assess the efficiency of innovation. The article presents the structure of sub-indices from the point of view of organizing activities and evaluating efficiency, a set of indicators and their sources, and a calculation method. The utmost importance of intellectual resources determining the effectiveness of the NIS is emphasized. The authors offer the original definition of intellectual resources as a set of forms (physical, mental, social, emotional, spiritual, and adaptive), their use in the NIS determines their development and the increment of the latest knowledge. In the process of innovative activities, intellectual resources through the commercialization of scientific research, development of an intellectual product and the production of innovations determine the level of development of the intellectual capital of the national economic system. The article gives an example of calculating the IAI and its sub-indices for the NIS of the Republic of Belarus. The authors analyze the IAI dynamics and its sub-indices; they show the deviations of the elements that make up the sub-indices; the article identifies the development zones of the NIS of the Republic of Belarus. The growth of NIS IAI is inferred. However, negative trends in the sub-indices "Science" and "Intellectual Resources" cause the slowdown in the growth of IAI. Exposing the problem areas of the NIS of the Republic of Belarus, the article also offers guidelines for the improvement of the NIS of the Republic of Belarus.
\end{abstract}

Keywords: intellectual resources, research and development, innovation, national innovation system, intellectual activity index

\section{INTRODUCTION}

The present paradigm of managing the national innovation system (hereinafter - NIS) as an object of socio-economic development of the Republic of Belarus, as well as global economic trends aimed at the intellectualization of activities determine the priority of intellectual resources in the innovations reproduction technologies [1]
Intellectual resources as carriers of the latest knowledge through research and development, the production of innovations and the commercialization of a science-intensive product form not only the intellectual capital of the enterprise, but also the national economic system as a whole $[2,3]$.

The analysis of the achieved indicators for the development of science and innovation planned for 
2020 in the "National Strategy for Sustainable Socio-Economic Development of the Republic of Belarus until 2030" showed a number of negative aspects. Thus, the share of innovation-active organizations in their total number reached $19.5 \%$ against the planned $25.0 \%$; innovative products in the total volume of sold products of industrial organizations $-17.9 \%$ against the planned $21.5 \%$; off-budget sources in internal expenditures on research and development $-55.5 \%$ against $60.0 \%$; science intensity in 2020 amounted to $0.55 \%$ against the planned rate of $2.5 \%$. It is necessary to improve the methodology of strategizing the NIS of the Republic of Belarus by supplementing the "analysis" stage with a comprehensive assessment of the NIS development level, research on the mutual influence of indicators that evaluate its effectiveness in regards to intellectual resources $[4,5]$.

The analysis of research and statistical literature shows that there is no unified approach to the composition of intellectual resources at the micro and macro levels and their inclusion in a comprehensive assessment of the level of development of the NIS (Table 1).

Table 1. Composition of intellectual resources in various sources, criteria, structure

\begin{tabular}{|c|c|}
\hline Researchers & Criteria of Assessment, Structure \\
\hline M.K. Akhtyamov, N.A. Kuznetsova, L.V. Saakova [6] & National income and gross domestic product \\
\hline M.V. Galushko, Yu.Yu. Alabina [7] & The cost of innovation, the cost of education \\
\hline A.I. Tatarkin [8] & $\begin{array}{l}\text { Intellectual resource of society: intellectual resources of regions, } \\
\text { departments, organizations, staff }\end{array}$ \\
\hline K.M. Oganyan [9] & Intangible assets, human capital organization, corporate culture \\
\hline E.A. Yakovleva [10] & The complex of various forms of objectified knowledge \\
\hline Global Innovation Index [11] & $\begin{array}{l}\text { Resources for innovation: institutions, human capital and research, } \\
\text { infrastructure, business and domestic market development; } \\
\text { implementation of innovations; the development of technologies and the } \\
\text { knowledge economy; stimulation of creative activity }\end{array}$ \\
\hline European Innovation Scoreboard [12] & Framework conditions, investment, innovation, effects \\
\hline
\end{tabular}

Source: Compiled by the authors

To address this issue, it is proposed to develop the intellectual activity index (hereinafter - IAI) of the NIS of the Republic of Belarus to analyze intellectual resources in conjunction with management, which creates a favorable institutional environment for the functioning of the NIS as a management system 1) NIS of the Republic of Belarus developing the infrastructure of innovation activity ; 2) indicators of research and development determining the innovativeness of the product; 3 ) indicators of innovative activity producing innovation as a result of the effective use of intellectual resources, research and development, management system.

The relevance [13] of IAI NIS is determined by the development strategy of the national sociallyoriented economic system of the Republic of Belarus with its guidelines of development towards the $5^{\text {th }}$ $6^{\text {th }}$ technological orders [14], program documents of industries and directions of the national economy, as well as crisis phenomena in the global economic environment [15]. Thus, these circumstances justify the need to improve the NIS strategizing methodology through additional research on its development trends in the Republic of Belarus in regards to IAI, and to identify the development activities [16].

The novelty of the given research work is determined by:

1) The author's vision of the intellectual resources content, which structure includes physical, mental, social, emotional, spiritual, and adaptive abilities of an employee. Such structure of intellectual resources ensures the possible use of both qualitative and quantitative characteristics and their indicators. Intellectual resources are a set of labor abilities of employees involved in the NIS, they create the latest knowledge and form intellectual capital through the production of a science-intensive product and its commercialization.

2) The author's structure of IAI "Management", “Intellectual resources", "Research and development", "Innovative activity" - and its content, determined by the criteria of organization and efficiency.

\section{MATERIALS AND METHODS}

The research purpose is to improve the analysis of the methodology of NIS strategizing as an object of socio-economic development of the Republic of Belarus. Research objectives are to calculate the NIS IAI; to analyze its dynamics; to determine the directions of development. 
Statistical methods and methods of economic analysis were used for the research. The methodology for the analysis and assessment of IAI is presented in Table 2 .

The structure of the IAI and the indicators of its assessment are presented in Table 3. The structure of the IAI is based on two criteria: provision (organization of activities) and efficiency as a result of activities.
Table 2. Stages of the IAI assessment methodology

\begin{tabular}{|l|l|}
\hline № & \multicolumn{1}{c|}{ Stages of Methodology } \\
\hline 1. & Determination of the structure of IAI, sub-indices \\
\hline 2. & Selection of values \\
\hline 3. & Methodology definition \\
\hline 5. & Assessment of IAI sub-indices \\
\hline 6. & Assessment of IAI \\
\hline 7. & Study of dynamics and deviations of IAI \\
\hline 8. & Data interpretation \\
\hline
\end{tabular}

Source: Compiled by the authors

Table 3. Determination of the structure, indicators and sources of IAI

\begin{tabular}{|c|l|}
\hline \multirow{2}{*}{ No } & \multicolumn{1}{c|}{ Structure of IAI } \\
\cline { 2 - 3 } & $\begin{array}{l}\text { UP1-stability of environment } \\
\text { UP2-management: management efficiency; efficiency of regulation; effective compliance with laws } \\
\text { UP3-business: enforcement of contracts; lending terms; the possibility to start a business; bankruptcy procedure }\end{array}$ \\
\hline \multirow{2}{*}{2.} & $\begin{array}{l}\text { IR - intellectual resources } \\
\text { IR1-abilities: physical resource (health); mental resource (education); social resource } \\
\text { IR2-employment: the proportion of the workforce employed in the research sphere; the share of candidates of science } \\
\text { among those employed in the economy; the share of doctors of science among those employed in the economy }\end{array}$ \\
\hline \multirow{3}{*}{3.} & $\begin{array}{l}\text { NIR1-provision: the number of organizations carrying out research and development; R\&D costs } \\
\text { NIR2-efficiency: profit from implemented research projects; the profitability of the completed research work; coefficient } \\
\text { of inventive activity; issued patents; valid patents }\end{array}$ \\
\cline { 2 - 3 } & $\begin{array}{l}\text { ID - innovative activity } \\
\text { ID1-provision (technological innovations): the cost of technological innovations; the share of organizations that have } \\
\text { invested in technological innovations; number of organizations implementing technological innovations } \\
\text { ID1-provision (industry): the share of innovatively active enterprises; share of enterprises spending on technological, } \\
\text { organizational, marketing innovations } \\
\text { ID3-efficiency (industry): share of sold innovative products; the share of sold innovative products new to the domestic } \\
\text { market; share of sold innovative products new to the world market }\end{array}$ \\
\hline
\end{tabular}

Source: Compiled by the authors from [12, 17, 18]

The collection of data [19] for calculating the IAI differs in that the selected research period is relatively short because the formation of NIS started in 2012; consequently, the official statistical sources contain the systematized data only for this period. We use different databases of analytical systems: databases of international rating agencies, statistical databases. This approach leads to the following differences:

1) differences in measurement units: people, units, \%, rbl;

2) differences in dimension: mln., thousand, tens;

3) differences in approaches to indicators assessment used by various international rating agencies;

4) differences in time-series of statistical sources of the Republic of Belarus and international rating agencies.

Therefore, at the beginning of the calculations, the data are processed (normalized) for the commensurability of all indicators. The method of linear scaling was used, which allows determining all values in the interval $[0,1]$, where 0 is the minimum value of the indicators, and 1 is the maximum.

The calculation of the IAI of NIS of the Republic of Belarus is carried out using the method of averaging values, which involves the calculation of average values for the elements of sub-indices for each year and the subsequent calculation of the index value as an average for the sub-indices. This is the most optimal calculation method under the assumption that all elements of the index are in equilibrium and take values in the range from zero to one.

\section{RESULTS}

The dynamics of the calculated values of Republic of Belarus NIS IAI and its components are shown in Figure 1.

The analysis of the dynamics shows a $34 \%$ decrease in IAI in 2015 if compared to 2012. However, by 2020 , the index grew by $43 \%$. The growth of IAI is provided by an increase in the subindices "Management" and "Innovation"; at the same time, the "Intellectual resources" indicator showed a significant decrease while the "Research 
and development" indicator had a stable level. Below, we will analyze them in detail.
Figure 2 shows the dynamics of the "Management" sub-index

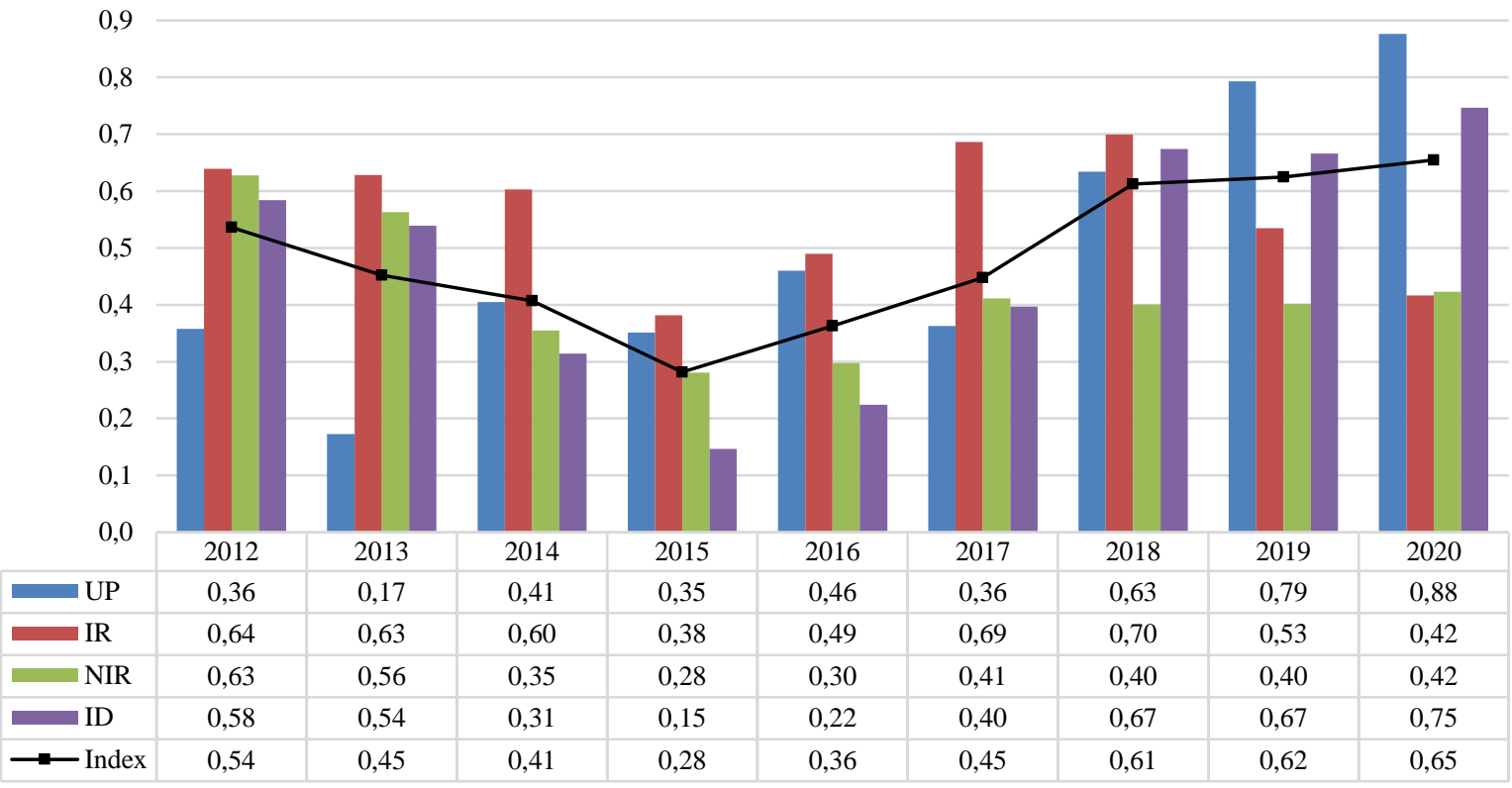

Figure 1. Republic of Belarus NIS IAI and its components Source: Compiled by the authors

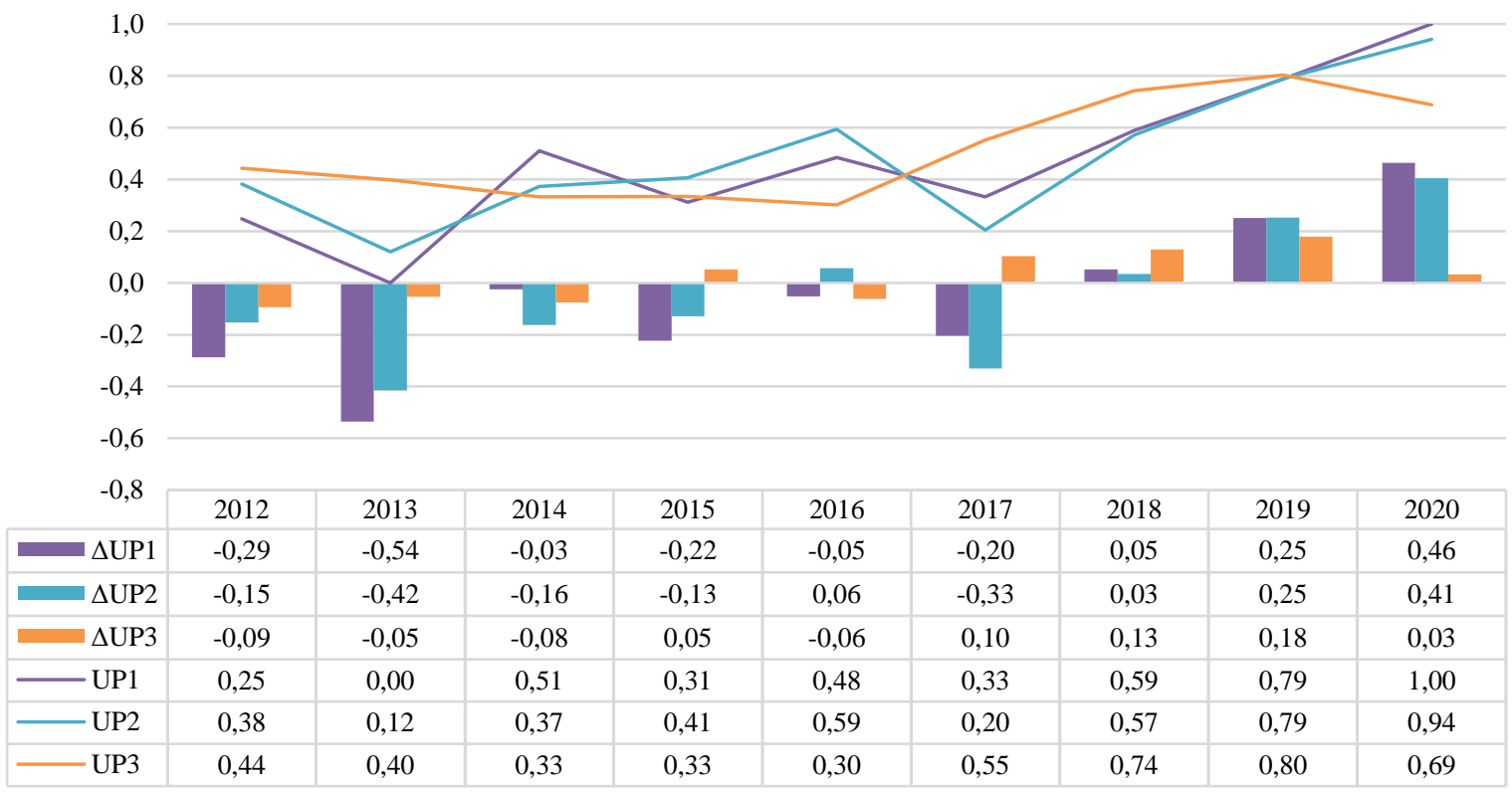

Figure 2. Trends in the components of the "Management" sub-index and their deviations from the integral IAI Source: Compiled by the authors

The dynamics of the "Management" sub-index shows positive trends. However, since 2019, there has been a decrease in the element of business activity (UP3), associated with a decrease of the rating in the sphere of guarantees of contract performance and stability of the business environment. Deviations of the "Management" elements from the integral assessment of IAI have been characterized by positive values since 2017, which indicates the stability of the management system providing institutional conditions and infrastructure for innovation.

Figure 3 shows the dynamics of the "Intellectual resources" sub-index. 


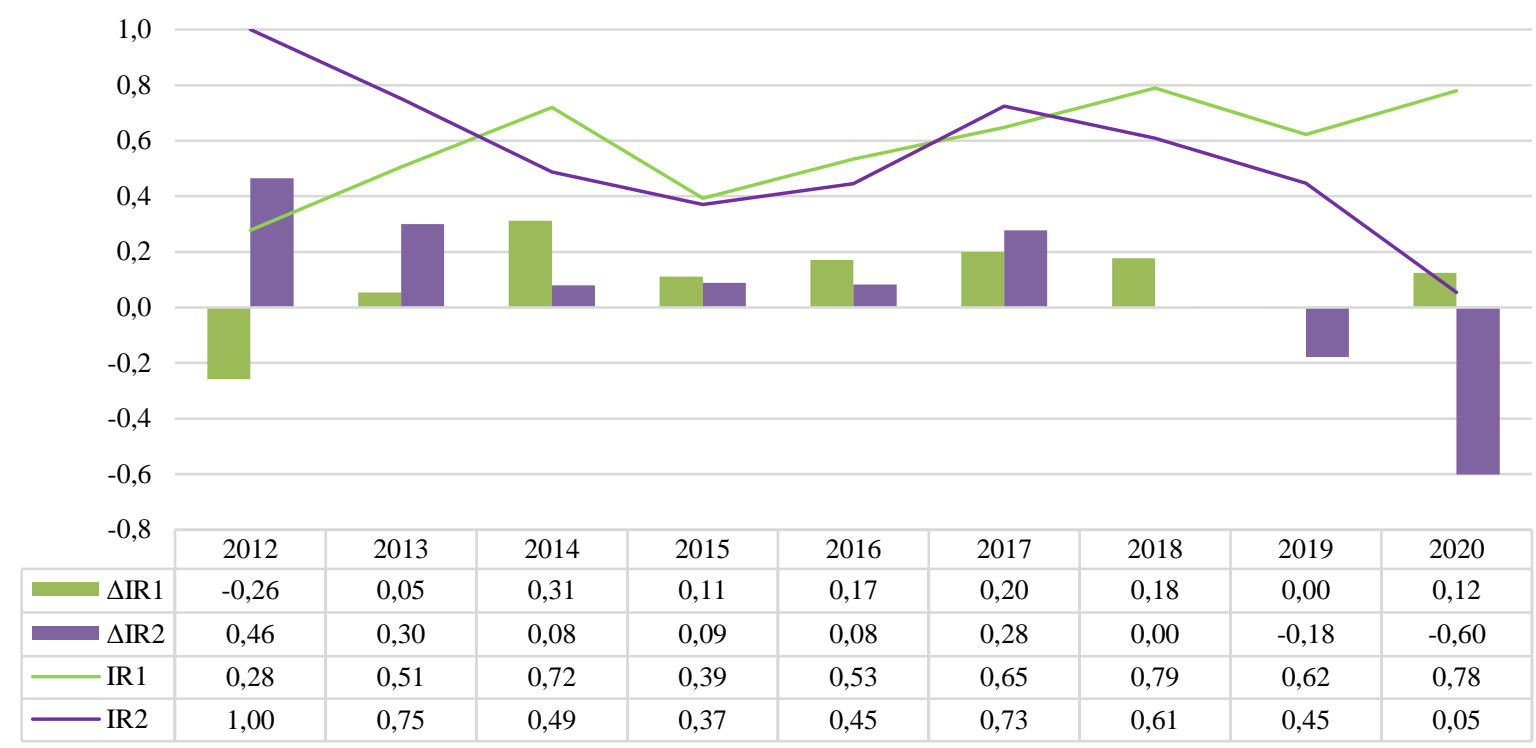

Figure 3. Trends in the components of the "Intellectual resources" sub-index and their deviations from the integrated IAI

Source: Compiled by the authors

The IR1 element of the "Intellectual resources" sub-index, which characterizes the quality of an intellectual resource, shows, in general, a positive trend. IR2, the quantitative component of the "Intellectual resources" sub-index, has been sharply falling since 2017 due to a decrease in the number of scientists and employed in the economy.

The share of candidates and doctors of sciences engaged in innovative activities is decreasing due to the aging of the population and the unattractiveness of research careers among young people. Deviation of IR2 has been in the negative zone since 2018 .
Analysis of the dynamics of the "Research and development" sub-index (Figure 4) shows an increase in the NIR1 indicator, provided by an increase in the number of organizations engaged in research and development.

Since 2012, there has been a 3-fold decrease in the value of NIR2. Deviations of NIR2 from the integral assessment are characterized by negative values since 2017; moreover, deviations of NIR1 have been following the same trend since 2012, although with an overall positive trend.

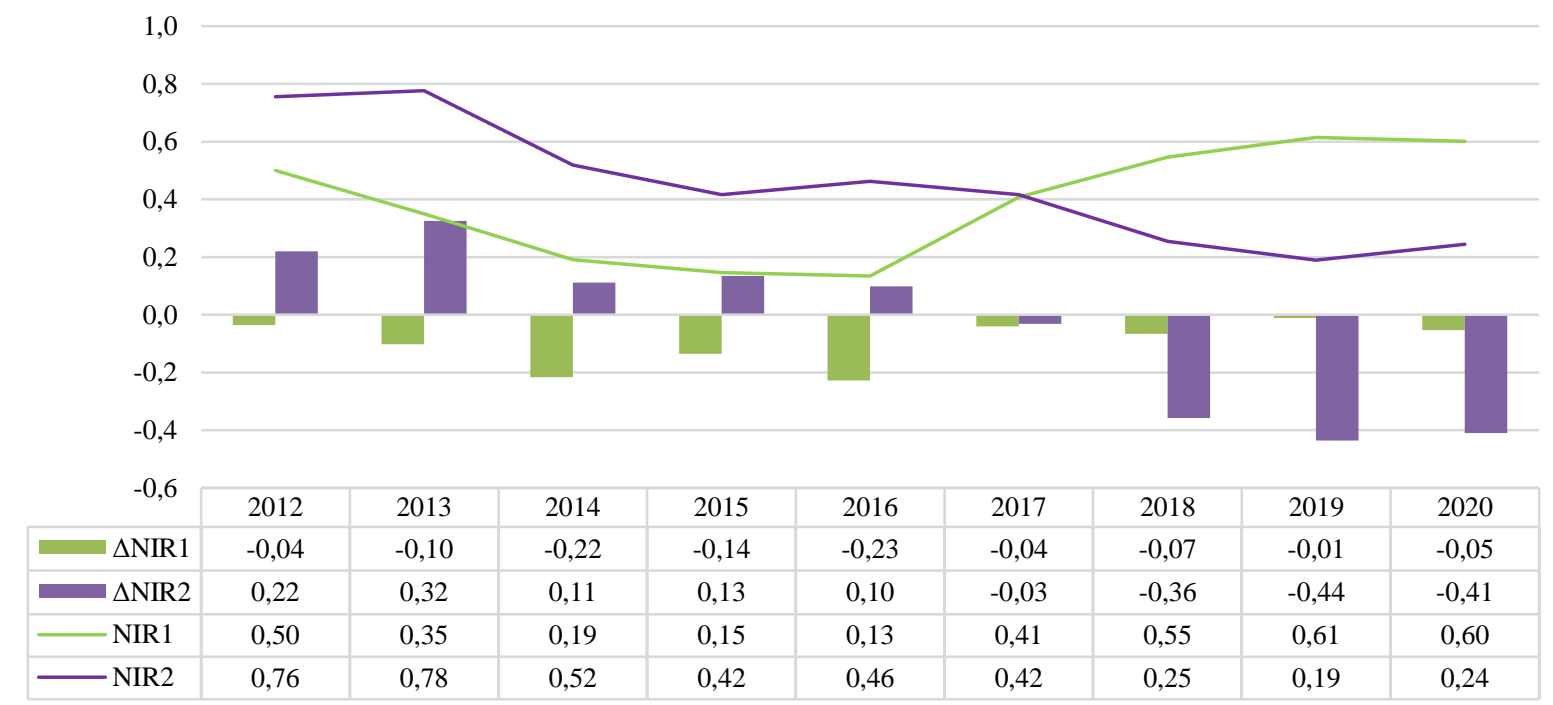

Figure 4. Trends in the components of the "Research and development" sub-index and their deviations from integral IAI

Source: Compiled by the authors 
The "Innovation activity" sub-index characterizes the innovative activity of enterprises (Figure 5). After the falling in the period 2012-2015, indicators of provision (ID1, ID2) show positive dynamics. However, the downward trend in the efficiency of innovation activity from 2018 to 2020 indicates a decrease in the share of sold innovative products by almost $30 \%$. In 2020, the deviation of ID3 from IAI is in the negative zone, ID1 and ID2 are in the positive zone.

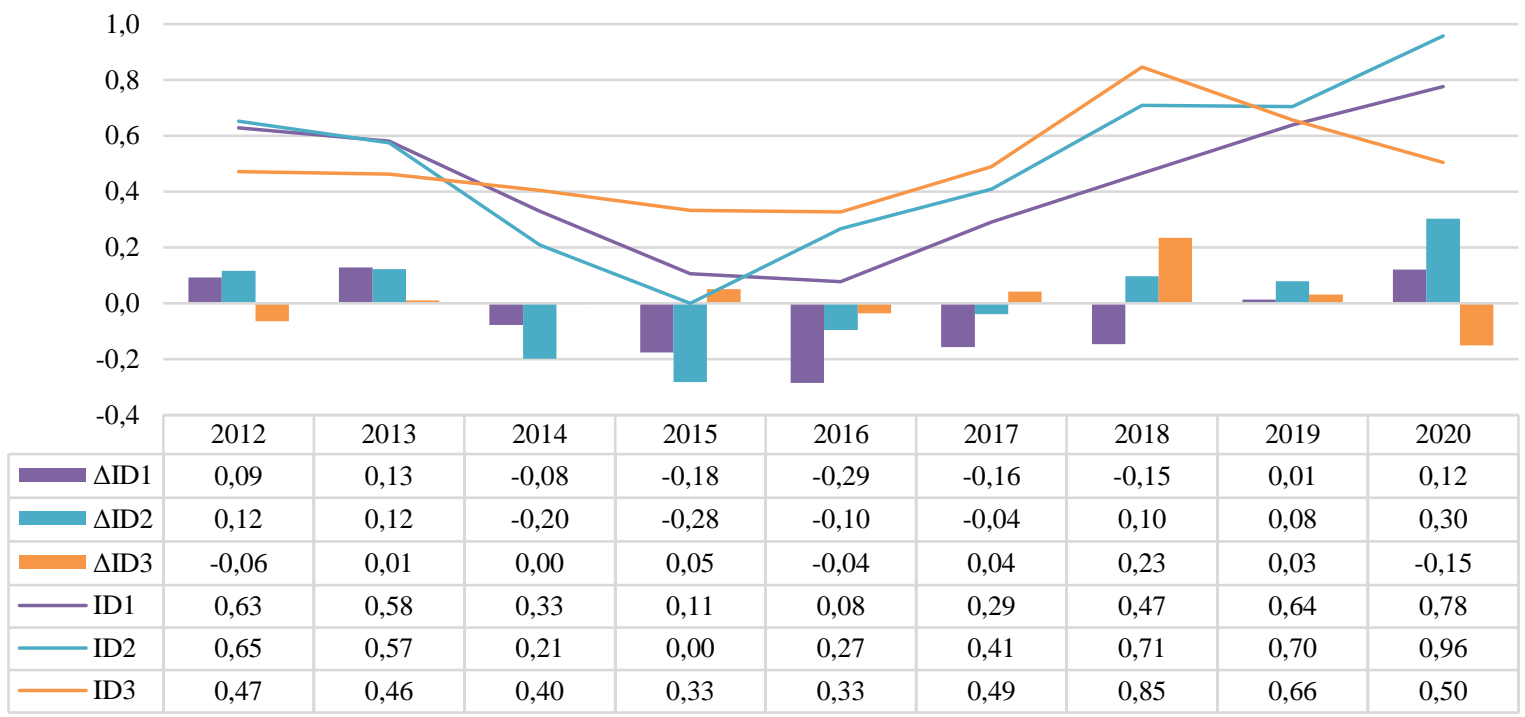

Figure 5. Trends in the components of the "Innovative activity" sub-index and their deviations from the integral IAI

Source: Compiled by the authors

On the basis of values deviations of the IAI elements from its final estimate for 2020, 4 groups of indicators were defined; they determine the level of development of the elements of the IAI NIS subindices and the degree of development trends improvement of the Republic of Belarus NIS (Table 4).

Table 4. Grouping of the results of deviations of sub-indices from the integrated IAI

\begin{tabular}{|c|c|c|c|c|}
\hline $\mathbf{N}$ & \multicolumn{2}{|r|}{ Characteristic of elements' deviations } & Deviation Interval & Value \\
\hline 1. & $\begin{array}{l}\text { Extremely } \\
\text { low }\end{array}$ & $\begin{array}{l}\text { Basic elements require detailed analysis and a new } \\
\text { development strategy }\end{array}$ & $-\infty ;-0.01$ & $\begin{array}{c}\Delta \mathrm{IR} 2=-0.601 \\
\Delta \mathrm{NIR} 1=-0.05 \\
\Delta \mathrm{NIR} 2=-0.410 \\
\Delta \mathrm{ID} 3=-0.150\end{array}$ \\
\hline 2. & Low & $\begin{array}{l}\text { Basic elements require monitoring, detailed analysis and } \\
\text { assessment, adjustments of tactical aspects of performance }\end{array}$ & $-0.01 ; 0.05$ & $\triangle \mathrm{UP3}=0.033$ \\
\hline 3. & Average & $\begin{array}{l}\text { Basic elements require monitoring and detailed analysis of } \\
\text { the situation }\end{array}$ & $0.05 ; 0.2$ & $\begin{array}{l}\Delta \mathrm{IR} 1=0.125 \\
\Delta \mathrm{ID} 1=0.122\end{array}$ \\
\hline 4. & High & Basic elements must be monitored & $0.2 ;+\infty$ & $\begin{aligned} \Delta U P 1 & =0.464 \\
\triangle U P 2 & =0.405 \\
\Delta I D 2 & =0.303\end{aligned}$ \\
\hline
\end{tabular}

Source: Compiled by the authors

The zone of an extremely low level of development includes: employment, research and development activities, and the efficiency of innovation, which implies the priority need to form a new paradigm of state management of their development [20]. Business management is at a low level of development, which necessitates the improvement of the public administration paradigm. The average level of development corresponds to the ability of intellectual resources and the provision of innovative activities [21-23]; it requires regular monitoring and assessment of the situation, adjustment of the development directions. The rest of the sub-indices elements are in a high zone of the NIS development level and need to be monitored and controlled.

\section{DISCUSSION}

Summing up the results of the research carried out on the basis of the above calculations, it can be argued that the NIS of the Republic of Belarus, in general, is developing dynamically: in 2020 against 2012, the growth of IAI was $22 \%$. 
The analysis of the indicators shows that since 2015 , the high growth of the "Intellectual resources" sub-index in the context of the positive dynamics of the "Management" index has ensured an increase in the efficiency of "Research and development" and, as a result, an increase in the efficiency of "Innovation activities" and IAI in general. The slowdown in the growth of the "Intellectual resources" sub-index since 2018 and, in particular, a sharp decrease in IR2 influenced a decrease in the growth rate of the "Research and development" subindex (a sharp decrease in the inventive activity ratio) and a slowdown in the growth rate of IAI. The positive dynamics of the "Innovative activity" subindex is connected with the content of the innovation reproduction process, in which there is a time lag from the creation of intellectual property objects to the introduction of an innovation into production. That is, the growth of the sub-index "Intellectual resources" in 2015-2017 ensured a positive trend in the "Research and development" sub-index (by $40 \%$ ) and a subsequent increase in the efficiency of "Innovation activity".

The analysis of the above-described dynamics of deviations for 2020 showed significant negative deviations of the "Intellectual resources" sub-index, it is caused by a drop in the proportion of staff engaged in research and development, a decrease in the proportion of candidates and doctors of sciences, as well as their low efficiency. Low efficiency is also explained by the age factor (aging of scientific personnel): $80 \%$ of employees with doctoral degrees employed in the innovation sphere are 70 years old and older; $40 \%$ of employees with candidate of science degrees are 60 years of age or older. The negative aspect of such tendencies is explained by the fact that, according to psychologists, the dynamics of intellectual activity begins to slow down, which negatively affects the dynamics of the reproduction of an intellectual product.

The sub-index "Research and development" is in the negative segment of deviations from the integral assessment of the NIS IAI. The greatest deviation is shown by the element of NIR2 - efficiency, which is evident in the results of intellectual activity: the coefficient of inventive activity, issued patents, valid patents. These trends are determined not only by negative trends in the "Intellectual resources" subindex, but also by imperfections in the legislative and regulatory framework that supports the mechanism for creating intellectual property [24], underdeveloped infrastructure of the intellectual property market, and low expenditures on research activities.
Deviations of the "Management" sub-index from the integral IAI are in the positive zone. However, the UP3 element (business) turned out to be in the zone $-0.01<\mathrm{n}<0.05$, requiring new approaches to creating a business environment, which is confirmed by the underdevelopment of the intellectual property market.

\section{CONCLUSION}

Thus, the results of this study confirm the authors' hypothesis about the key role of intellectual resources in the NIS of the Republic of Belarus, which determines the level of its development.

The development and calculation of the integral IAI, as well as the analysis of the dynamics of subindices and their deviations from the IAI showed that the intellectual abilities of staff involved in research activities through the reproduction of innovations and their commercialization create an increase in knowledge and, ultimately, intellectual capital.

For the development of intellectual resources, it is necessary to create a new strategy, based on a fundamentally new approach to organizing social and material conditions that increase the motivation and involvement of intellectual resources in the innovative activities of the NIS. It is necessary to create a system of stimulating young researchers' involvement in research activities, ensuring the research and defense of candidate's and, most importantly, doctoral dissertations, as an indicator of increasing the level of intellectual resources' development.

The management of the NIS of the Republic of Belarus is characterized, in general, by positive trends, it is mostly ensured by an electronic government system and the digitalization of the economy. The identified negative trends in the business element (UP3) confirm the main paradigm of the institutional model of the Republic of Belarus - a socially-oriented market state, which stability is ensured by a strong state power. The gradual transition to a market economy is determined with the slow development of the market, which has been confirmed by the studies. It is obvious that additional measures could stimulate the development of market relations and the intellectual property market, in particular.

Thus, the article shows the importance of improving the strategizing methodology of the NIS of the Republic of Belarus by introducing the NIS IAI into the analytical apparatus. 


\section{AUTHORS' CONTRIBUTIONS}

Elena E. Golovchanskaya, Yury V. Daneykin are responsible for the general research management, development of the idea and logic of the research, the framework of the article and its final version; Irina A. Karachun is responsible for the data collection and processing, for the research correction.

\section{REFERENCES}

[1] E.E. Golovchanskaya, "Development of intellectual resources of the Republic of Belarus: theory, methodology, practice" [Razvitiye intellektual'nykh resursov Respubliki Belarus': teoriya, metodologiya, praktika], Minsk: BGU, 2018. (In Russ.).

[2] D. Meissner, "Public-Private Partnership Models for Science, Technology, and Innovation Cooperation", Journal of the Knowledge Economy, 2019, vol. 10, pp. 13411361. DOI: $10.1007 / \mathrm{s} 13132-015-0310-3$

[3] "Innovation in science, technology and industry", Organization for Economic Cooperation and Development, 2021. Retrieved from: https://www.oecd.org/innovation/inno/

[4] O.B. Digilina, D.V. Lebedeva, "Methodological tools for managing intellectual resources: overcoming limited resource potential", RUDN Journal of Economics, 2021, vol. 29(1), pp. 99113. DOI: 10.22363/2313-2329-2021-29-1-99113

[5] A.E. Suleimankadieva, E.A. Tkachenko, M.A. Petrov, O.Y. Syrovatskaya, R.V. Klyarovskaya, "Methodological aspects of intellectual capital valuation of a global company in modern conditions", In Proceedings of 17 IC on Intellectual Capital, Knowledge Management and Organizational Learning, 2020, pp. 346-353. DOI: 10.34190/IKM.20.061

[6] M.K. Akhtyamov, N.A. Kuznetsova, L.V. Saakova, "Substantiation of criterion of efficiency of intellectual resources usage", Creative Economy, 2011, vol. 5(53), pp. 17-25. (In Russ.).

[7] M.V. Galushko, Yu.Yu. Alabina, "Use of intellectual potential as a condition of innovative development of the region", Russian Journal of Innovation Economics, 2019, vol. 9(3), pp. 771-786. (In Russ.). DOI:

\subsection{4/vinec.9.3.40878}

[8] A.I. Tatarkin, "Intellectual resource of the society and its role in the social-economic development" [Intellektual'nyy resurs obshchestva: sushchnost', klassifikatsiya i rol' v sotsial'no-ekonomicheskom razvitii], The Chelyabinsk Humanitarian Journal, 2010, vol. 3(12), pp. 6-22. (In Russ.).

[9] K.M. Oganyan, “Management of Organization's Intellectual Resources" [Upravlenie intellektual'nymi resursami organizacii], $\mathrm{SPb}$.: SPbSUE, 2013. (In Russ.).

[10]E.A. Yakovleva, "Management of intellectual resources of employees in the conditions of innovative development in the digital economy", Creative Economy, 2018, vol. 12(8), pp. 1073-1088. (In Russ.). DOI: 10.18334/ce.12.8.39292

[11] Global Innovation Index, 2021. (In Russ.). Retrieved from: https://www.wipo.int/global_innovation_index/r u/2020/

[12]European Innovation Scoreboard, 2021. Retrieved from: http:// https://ec.europa.eu/growth/industry/policy/inno vation/scoreboards_en

[13] S. Ren, Z. Song, "Intellectual capital and firm innovation: incentive effect and selection effect", Applied Economics Letters, 2021, vol. 28(1), pp. 1-7. DOI: 10.1080/13504851.2020.1767281

[14]"National Strategy for Sustainable Social and Economic Development of the Republic of Belarus for the period up to 2030", 2017. (In Russ.). Retrieved from: http://www.economy.gov.by/uploads/files/NSU R2030/Natsionalnaja-strategija-ustojchivogosotsialno-ekonomicheskogo-razvitijaRespubliki-Belarus-na-period-do-2030-goda.pdf

[15]E.V. Yakovleva, “Intellectual employees' resources management of innovative industrial enterprises in the digital environment", In Proceedings of ISC "Digital Transformation on Manufacturing, Infrastructure and Service", 2020 , pp. 12-86. DOI: $10.1088 / 1757-$ 899X/940/1/012086

[16]E.M. Lavrischeva, A.K. Petrenko, B.A. Pozin, "Technology of assembly of intellectual and information resources internet", In CEUR Workshop Proceedings of the 21st Conference 
on Scientific Services and Internet, 2020, pp. 247-273.

[17] The Legatum Prosperity Index 2020, 2021. Retrieved from: https://www.prosperity.com/about/resources

[18] National Statistics Committee of the Republic of Belarus, 2021. (In Russ.). Retrieved from: http://belstat.gov.by/

[19] I. Shani, "Traditions of Systems theory: An observer report", Constructivist Foundations, 2019, vol. 15(1), pp. 78-81.

[20] L. Steinfield, D. Holt, "Toward A Theory on the Reproduction of Social Innovations in Subsistence Marketplaces", Journal of Product Innovation Management, 2019, vol. 36(6), pp. 764-799. DOI: 10.1111/jpim.12510

[21]C. Chiarolla, "Intellectual property from a global environmental law perspective: Lessons from patent disclosure requirements for genetic resources and traditional knowledge", Transnational Environmental Law, 2019, vol. 8(3), pp. 1-19. $10.1017 /$ S2047102519000165

[22]N.A. Spassiani, B.A. Meisner, M.S. Abou Chacra, T. Heller, J. Hammel, "What is and isn't working: Factors involved in sustaining community-based health and participation initiatives for people ageing with intellectual and developmental disabilities", Journal of Applied Research in Intellectual Disabilities, 2019, vol. 32(6), pp. 1465-1477. DOI: $10.1111 /$ jar. 12640

[23] J. Duncan, "Confessions of an Intellectual Freedom Novice", Journal of Library Administration, 2019, vol. 59(7), pp. 786-800. DOI: $10.1080 / 01930826.2019 .1649964$

[24]E.E. Golovchanskaya, L.S. Shakhovskaya, A.I. Korotkevich, M.V. Lysiankova, "Intellectual resource as a key resource of entrepreneurial activity in the structure of assessment of the national (Russia) economy's intellectual activity: Theory and methodology of research", Espacios, 2018, vol. 39(28), pp. 18. 